\title{
The Impact of FDI on the Economic Growth of Sri Lanka: An ARDL Approach to Co-integration
}

\author{
${ }^{1}$ NPG Samantha, 2 Liu Haiyun \\ 1,2 School of Economics, Huazhong University of Science and Technology, Wuhan, Hubei, \\ P.R. China
}

\begin{abstract}
The impact of foreign direct investment(FDI) on host country economic growth is a debatable issue in the recent economic literature. The purpose of this study is to examine this issue for a country which practiced comparatively more liberal economic policies within the South Asian region over four decades. The ARDL approach to cointegration is applied to identify long-run relationship and short-run dynamics between selected variables for the period of 1978 to 2015 for Sri Lanka. The empirical result confirms the long run relationship between the variables. FDI is positively correlated with economic growth in the short run and long run, but it is not a significant factor for economic growth in Sri Lanka. Sri Lanka will have to undertake policy reforms related to FDI in order to attract more greenfield investments to boost economic growth creating new job opportunities and expanding exports in the manufacturing sector. These findings would be an example for other small open economies with similar economic characteristics.
\end{abstract}

Keywords: FDI, Economic growth, ARDL approach, Co-integration, Stability and diagnostic analysis, Long-run relationship

\section{Introduction}

The relationship between FDI and economic growth has been extensively discussed in the economic literature. Theoretically, FDI is considered as a significant factor for economic growth due to many reasons. It plays a key role in transferring advanced technology which is available in developed countries to developing countries. FDI improves human capital and institutes in host country stimulating domestic investment. FDI provides relatively more stable funds, increase employment and trade; create backward and forward linkages across sectors with the new production process. Further it is argued that high-tech knowledge, technology, and managerial skills can be spill-over from foreign firms to domestic firms improving the productivity of local firms (Athukorala, 2003; Balasubramanyam et al.,1996; Hakimi \& Hamdi, 2016; Haruna, 2012; Iamsiraroj \& Ulubaşoğlu, 2015; Mahmood, 2013; Makki \& Somwaru, 2004; Tsai, 1995; Zilinske, 2010).

Even with the traditional belief of FDI to economic growth, empirical literature finds a positive, negative or weak relationship between FDI and economic growth. Agrawal \& Khan (2011), Agrawal (2015), Alfaro et al. (2010), and Silajdzic \& Mehic (2016) argue that the impact of FDI on economic growth depends on the country-specific situation. It differs from country to country. The impact level of FDI on economic growth depends on how capable the host country in attracting and utilizing foreign capital, technology, managerial skills, and backward and forward linkages. Hence, a country level study with specific conditions provides policy directions to achieve economic goals for developing countries. 


\subsection{Problem Statement}

In 1977, as the first country in the South Asian region, Sri Lanka introduced a comprehensive package of liberalized economic policies with the objective of rapid economic growth. All the successive governments after 1977 rely on international trade and international investment as a tool for economic growth. Like many other developing countries, Sri Lanka also adjusted FDI policies in order to develop a favorable environment for foreign investments. Comparison with the other developing countries especially East and South-east Asian countries, it is questionable whether Sri Lanka could achieve the development goals as expected in policy reforms.

Sri Lankan economy is facing many challenges at present. ADB (2016) stated that Sri Lanka has been moving toward a debt trap due to inability to service foreign loans, high fiscal deficit, and limited foreign currency reserves. Development strategy of the coalition government which came to power in 2015 is to facilitate investment both in domestic and foreign focusing on job creation, rural development, linking up to the global value chain and attracting more foreign direct investments (ADB, 2016). Sri Lanka has been performing poorly in terms of attracting FDI. It is argued that the long-lasting internal conflict which was ended in 2009, was one of the main reasons for weak performance on FDI recipients. Even after the civil war in 2009, Sri Lanka could not perform well in attracting FDI. Based on annual FDI inflow data extracted from UNCTAD database, FDI inflows to the country has been declining since 2010. The annual FDI inflows to the country in 2010 was 955.91 million USD and dropped to 681.24 million USD in 2015. As a percentage of GDP, FDI inflows to the country account for only 0.89 in 2015 and continuously been declining since 2011 (UNCTAD,2016). In last four decades, Sri Lanka employed different incentives to attract FDI, trade liberalizations and market reforms in various sectors of the economy to reduce restrictions on FDI and develop the scope of FDI in different sectors of the economy. It is questionable whether the FDI stimulate economic growth in Sri Lanka.

\subsection{Aim of the study}

The aim of this study is to analyze the impact of FDI on the economic growth in Sri Lanka for the period of 1978 to 2015. ARDL approach is applied to examine the long-run relationships and the short run dynamics between the variables under consideration. The empirical findings will provide policy implications related to FDI-economic growth nexus for developing countries like Sri Lanka.

\section{Literature Review}

The debate related to the impact of FDI on the economic growth is existing with heterogeneous empirical findings. Some empirical studies end with positive relationships between these two variables while others conclude with negative, weak or no relationships. In an important study conducted by Borensztein et al. (1998), argue that the effect of FDI on economic growth depends on host country absorptive capacity. FDI consists of advanced technology than domestic investment. Thus, host country should have enough human capital to absorb advanced technology. Impact of FDI on economic growth depends on the utilization of advanced technology. By analyzing panel data of 18 Latin American countries for the period of 19701999, Bengoa \& Robles (2003) find that FDI is positively correlated with economic development if the host country consists of adequate human capital, economic stability, and liberalized markets. Makki \& Somwaru (2004) analyze the relationship between FDI and economic growth using cross-section data for sixty-six developing countries for three decades. They extend the argument that developing countries are beneficial of FDI with transferring advanced technology. Having a better stock of human capital, sound macroeconomic policies, and institutional stability are found as a precondition for FDI driven growth.

Gao (2005) develops a model combining elements of the new economic geography model and the endogenous growth model. In the process of economic integration, economic growth and 
FDI are simultaneously determined. With the relocation of firms output to the previously peripheral country, wage rate falls due to release of resources from manufacturing output in manufacturing center. As a result, research and development in the innovating country expand the lowering cost of innovation, ultimately causing world growth rate rises. Lower barriers to trade, better transportation, and communication facilities enhance the capacity of international outsourcing. Due to this, more resources are shifted to innovating activities in technologically advanced countries. Such a development can potentially increase the rate of economic growth in the world. In a sample of 31 developing countries, Hansen \& Rand (2006) analyze the causal relationship between FDI and GDP. The study is based on the standard neoclassical growth model and find a strong causal link between FDI to GDP in both short and long run. FDI regards as a growth-promoting factor like domestic investment and it has a long run impact on GDP irrespectively of the level of development.

Fedderke \& Romm (2006) analyze the impact and determinants of FDI in South Africa for the period of 1956-2003 and find a positive impact of FDI on economic growth. Complementarity relationship is found between foreign and domestic capital in long run implying a positive spillover from foreign to domestic capital. In the short run, the positive impact of FDI on economic growth is restricted due to crowd-out of domestic investment from FDI. Alfaro, et al., (2010) argues that the financially developed countries are more benefited and lead to higher growth rates from an increase in FDI with compared to financially poorly developed ones. The local condition is highly effective in enhancing the efficiency of FDI on economic growth. Countries have to be careful when implementing policies attracting FDI that is complementarity to local production.

Agrawal \& Khan (2011) attempt to investigate the effect of FDI on economic growth of China and India modifying a growth model from the basic growth model. Human Capital, Labor Force, FDI and Gross Capital Formation are used as independent variables while selecting GDP as the dependent variable. OLS method of regression confirms a positive relationship between FDI and economic growth. It is also found that FDI is less significant to predict economic growth compared to other variables. Market size, easy accessibility to export market, government incentives, developed infrastructure, cost-effectiveness, and macroeconomic climate of China are more constructive to India attracting foreign investors. Soltani \& Ochi, (2012) examine the relationship between FDI and economic growth of Tunisia for the period of 1975-2009. Cointegration and error correction models are applied to test the short and long-run relationship between the variables. The study finds a positive effect of FDI on growth.

Iamsiraroj \& Ulubaşoğlu (2015) Identify five new and important results related to cross country FDI- growth relationship using global data of 140 countries for the period 1970 to 2009. FDIgrowth relationship is stronger in regional unite variation than in country variation because of a region is a larger unite hosting sufficiently different type of FDI. Financial development and trade openness are found to be the most important absorption factors in FDI to economic growth. Macroeconomic stability of a country is strongly affected by FDI- growth relationship. No evidence finds to prove that FDI beneficial to developing countries than developed. Hence, FDI is positively related to growth in globally. Agrawal (2015) analyzes the relationship between FDI and economic growth for BRICS economics for the period of 1980-2012. Co-integration of variables is checked using pair-wise Granger causality analysis and VEC Granger causality Wald test. The result shows long-run equilibrium relationship between FDI and economic growth. Removal of barriers to FDI inflows and improvement of absorptive capacity is suggested to achieve maximum positive growth.

Some empirical studies find a weak relationship between FDI and economic growth. Akinlo (2004) finds a weak relationship between FDI and economic growth for Nigerian data over the period of 1970-2001. Inward FDI in Nigeria has targeted mainly oil extracting industries. The results of the study are in line with the argument that extractive FDI might not be in growth- 
enhancing as manufacturing FDI. Some scholars argue that financial market is a prerequisite for the positive effect of FDI on economic growth. Azman-Saini et al. (2010) analyze the relationship between FDI and economic growth for 91 countries over the period of 1995-2005 and find that FDI on growth boost only after financial market development exceeds minimum required level. Haruna Danja (2012) support the argument of FDI is not much contributed to economic growth due to the repatriation of profits, interest payment on foreign loans and contract fees. Masry (2015) finds very weak and non-significant effect of FDI on economic growth in Egypt over the period of 1961-2012. Egypt has failed to attract labor-intensive FDI which create job opportunities. Lack of having a proper investment map and institutional setup is also negatively affected on attracting FDI.

By analyzing the impact of FDI and DI on economic growth in Sub-Sahara African countries, Adams (2009) finds a weak positive relationship between FDI and economic growth. FDI may positively relate to an increase in total factor productivity rather than augmentation of domestic capital. Falki (2009) finds a negative and statistically insignificant relation between FDI and economic growth for time series data over the period of 1980-2006 in Pakistan. He emphasizes the need for more greenfield investment expanding manufacturing sector to increase export and economic growth. Belloumi (2014) analyzes the relationship of FDI, trade openness and economic growth in Tunisia for the period of 1970-2008. He uses ARDL bound test and Granger causality test to identify the short-run and long-run dynamics among the variables. The findings of the study show insignificant causality between FDI and economic growth. The results of the study go against the generally accepted idea of the positive impact of FDI on economic growth to be automatic. Herzer et al. (2008) also challenge the common belief of FDI to promote economic growth analyzing time series data of 28 countries using cointegration technique. The study finds no effect of FDI on economic growth neither a long run nor short run for the majority of countries. The effect of FDI on economic growth differ between countries, type, and sector of destination. According to the results, in case of developing countries, there is no clear association between the growth impact of FDI and the level of per capita income, education, financial market development and the degree of openness.

The available empirical literature verifies that the impact of FDI on economic growth depends on the country-specific situation due to the variation of the socio-economic condition by country to country. It would vary from country to country, region to region, and time period to time period. Sri Lanka is a classic example of applying outward oriented market economic policies over four decades. Comprehensive studies related to the impact of FDI on economic growth of Sri Lanka are limited. This study will cover this literature gap covering the period from 19782015 and applying novel econometrics analysis.

\section{Research Methodology}

\subsection{Model Specification and Definition of Variables}

The model used in this study is derived in traditional manner form a production function. Akinlo (2004), Soltani \& Ochi (2012), Chaudhry, Mehmood, \& Mehmood (2013) Saqib et al. (2013), Maliwa \& Nyambe (2015) Chaudhry et al.(2013) have also used similar models to analyze FDIeconomic growth relationship. 


$$
\log G D P_{t}=\beta_{0}+\beta_{1} \log F D I_{t}+\beta_{2} \log D I_{t}+\beta_{3} \log T_{t}+\beta_{4} \log L_{t}+\varepsilon_{t}
$$

Where:

$$
\begin{aligned}
& \log G D P_{t}=\text { Log of real per capita gross domestic product } \\
& \log F D I_{t}=\text { Log of real FDI inflow } \\
& \log D I_{t}=\text { Log of real domestic investment } \\
& \log T_{t} \quad=\text { Log of trade openness } \\
& \log L_{t} \quad=\text { Log of labour force } \\
& \varepsilon_{t} \quad=\text { Error term }
\end{aligned}
$$

In neoclassical growth theory, Solow (1957) model explains the total output of the economy by the stock of capital, labor productivity, and total factor productivity. Technology and labor are exogenous in Solow model, hence, FDI increases the stock of capital promoting economic growth in the short run. In endogenous growth theory, long-run economic growth is explained endogenous way by technology and labor in contrast to the Solow model. Diminishing return to capital is compensated by externalities of advanced technology, thus FDI plays an important role in transferring advanced technology which is available in developed countries to developing countries. FDI is not only a source of capital but also a driver of knowledge transferring both in terms of labor training and skill acquisition and introducing alternative management practices and better organizational arrangements (Borensztein et al.,1998). The basic model of this study is based on endogenous growth theory where total production is a function of technology, capital, and labor. FDI is included in the model to represent the externalities and spill-over effects. The variables capital (domestic investment) and labor are major components in production function which determine the level of production. The control variable, trade openness will capture the externalities in relation to international trade and reduce the omitted variable bias.

Annual time series data related to GDP, domestic investment, trade, and labor were collected from the World Development Indicators (WDI) of World Bank. United Nations Conference on Trade and Development (UNCTAD) database was used to collect the data on FDI. This study covers the period from 1978-2015.

\section{Definition of variables GDP}

The GDP is the most important macroeconomic variable and it measured both a national total output of goods and services and its total income. The GDP per capita income is calculated dividing country's GDP by its total population over the specific time period. It is an indicator of standard of living and often used to compare the wealth of one nation over others. This study uses real GDP per capita income calculated based on 2010 price level and included as the dependent variable to the model.

\section{FDI}

In line with the objective of this paper, FDI is used as an explanatory variable to explain the FDI - economic growth relationship. FDI is shown in a country's balance of payment accounts and it is the sum of foreign equity capital and reinvestment of earning. Real FDI inflows for the period of $1978-2015$ is used in this study.

\section{Domestic investment}

Domestic investment is proxied by the Gross fixed capital formation (GFCF). GFCF is a flow variable and it measures the value of acquisitions of new or existing fixed assets by the business sector, government and households (excluding unincorporated enterprises) less disposable of 
fixed assets. This study uses the real value of GFCF as a control variable as done by Chaudhry et al., (2013).

\section{Trade Openness}

The variable trade openness is calculated taking the summation of exports and imports as a ratio to the GDP. Trade openness is an indicator of the level of trade liberalization of a country. The endogenous growth theories pioneered by Romer (1986) and its variants emphasis the trade openness-growth relationship. Technology is an endogenous variable in endogenous growth models, hence with the increase of openness, developing countries increase productivity and efficiency by using new technology which is available outside the country.

\section{Labor Force}

The labor force is used as a proxy for human capital. The total volume of the labor force is indicated by $L$.

\subsection{Econometric Methodology Unit Root Test}

Before applying for econometric work, it is a pre-requisite of checking stationary of series under consideration. According to Granger \& Newbold (1974), incorrect inferences would be generated working with non-stationary variables. Using Augmented Dicky-Fuller (ADF) unit root test, we checked the order of integration of selected variables.

\section{ARDL Approach}

ARDL approach to co-integration has many econometric advantages over previously developed Engle \& Granger (1987) and Johansen and Juselius (1990) co-integration techniques. First, it can be applied to variables integrated into order zero, order one or fractionally integrated. Secondly, it is relatively more efficient with small and finite sample size. The ability to obtain unbiased estimates of the long-run model is the third advantage (Belloumi, 2014). Considering above advantages and having small sample size the following ARDL model is applied to identify long-run relationship and short-run dynamics of FDI and economic growth in Sri Lanka.

$$
\begin{aligned}
\Delta \log G D P_{t}=\beta_{0} \sum_{t=1}^{q} & \beta_{1 t} \Delta \log G D P_{t-1}+\sum_{t=1}^{q} \beta_{2 t} \Delta \log F D I_{t-1}+\sum_{t=1}^{q} \beta_{3 t} \Delta \log D I_{t-1}+\sum_{t=1}^{q} \beta_{4 t} \Delta \log \\
& +\sum_{t=1}^{q} \beta_{5 t} \Delta \log L_{t-1}+\beta_{6} \log G D P_{t-1}+\beta_{7} \log F D I_{t-1}+\beta_{8} \log D I_{t-1}+\beta_{9} \log \\
& +\beta_{10} \log L_{t-1}+\varepsilon_{t}
\end{aligned}
$$

Where, $\Delta=$ first difference operator, $q=$ optimal lag length, $\beta_{1}, \beta_{2}, \beta_{3}, \beta_{4}$, and $\beta_{5}$ represent the short-run dynamics and $\beta_{6}, \beta_{7}, \beta_{8}, \beta_{9}$ and $\beta_{10}$ represent long-run elasticity. The error term is represented by $\varepsilon_{t}$.

\section{Error Correction Model (ECM)}

Error correction model which introduced by Engle and Granger (1987) is used to obtain information on causal factors affecting the variables in the model. The sign of the error correction term (ECT) of ECM indicates the long-run relationship between the variables. The negative sign of ECt indicates the convergence while the positive sigh indicates divergence, hence, to have a long-run relationship the sign of the ECT should be negative and significant. The following equation(Eq.3) presents the ARDL error correction version. 


$$
\begin{gathered}
\Delta \log G D P_{t}=\beta_{0} \sum_{t=1}^{q 1} \beta_{1 t} \Delta \log G D P_{t-1}+\sum_{t=1}^{q 2} \beta_{2 t} \Delta \log F D I_{t-1}+\sum_{t=1}^{q 3} \beta_{3 t} \Delta \log D I_{t-1}+\sum_{t=1}^{q 4} \beta_{4 t} \Delta l o t \\
+\sum_{t=1}^{q 5} \beta_{5 t} \Delta \log L_{t-1}+\lambda E C_{t-1}+\varepsilon_{t}
\end{gathered}
$$

Where, q1, q2, q3, q4, and q5 are optimal lag lengths, EC and $\lambda$ are represented the error correction term and the speed of adjustment parameter respectively.

\section{Wald Test Coefficient Restriction}

The Wald test provides information on the long-run coefficient of variables. The F-statistics which is generated by Wald test has to be compared with critical values of Pesaran, et al.(2001) table. Pesaran table provides lower I (0) and upper I (1) critical bounds. The null-hypothesis is rejected if the F-statistic is higher than the upper critical bound and it is accepted if the Fstatistics is lower than the lower critical bound. The test will be inconclusive if the F-statistics is between lower and upper critical bounds.

\section{Stability Test}

To test the structural stability of the model, we used CUSUM and CUSUMSQ test. The stability decision of parameter variation can be made on the figure plots of recursive residuals. CUSUM and CUSUMSQ tests generate figure plots using the sum of recursive residuals and sum of squared recursive residuals respectively. The lines of CUSUM and CUSUMSQ should be laid between critical lines, hence, the regression parameters are unstable if the lines cross the critical bounds.

\section{Data Analysis and Interpretation}

Before applying econometrics model, it is required to check the order of integration of selected variables. ADF unite root test is applied for this purpose. Table 1 exhibits the univariate analysis results of ADF unit root test for selected variables. According to the table 1 , only the variable log FDI is stationary on a level I(0) both for intercept and trend with intercept. After running the same test taking the first difference, all the variables became stationary with and without trend. Hence, the unit root test confirmed that the variables are stationary on different levels $\mathrm{I}(0)$ and $\mathrm{I}(1)$. If the variables are stationary on different levels, the most widely used methods identifying co-integration among variables such as Engle and Granger (1987) and Johansen and Juselius (1990) tests cannot be applied. It is rationalized of applying ARDL approach to cointegration due to variables are stationary on different levels $\mathrm{I}(0)$ and $\mathrm{I}(1)$ with small sample size.

\begin{tabular}{|c|c|c|c|}
\hline \multirow[t]{2}{*}{ Variable } & \multirow[t]{2}{*}{ Status } & \multicolumn{2}{|c|}{ ADF test statistics } \\
\hline & & Without trend & With trend \\
\hline LogGDP & Level & $2.2222 \quad(0.9999)$ & $-0.5417 \quad(0.9768)$ \\
\hline LogFDI & Level & $-4.4263 *(0.0012)$ & $-4.2284 * *(0.0102)$ \\
\hline LogDI & Level & $-0.2700 \quad(0.9199)$ & $-2.2758 \quad(0.4357)$ \\
\hline LogT & Level & $-0.6231 \quad(0.8532)$ & $(0.8999)$ \\
\hline LogL & Level & $-0.8865 \quad(0.7814)$ & $(0.1956)$ \\
\hline$\Delta$ LogGDP & First difference & $-4.2688 *(0.0008)$ & $-4.8089 *(0.0023)$ \\
\hline$\Delta$ LogFDI & First difference & $-6.1370 *(0.0000)$ & $-6.0528^{*}(0.0001)$ \\
\hline$\Delta$ LogDI & First difference & $-5.1297 *(0.0002)$ & $-5.1479 *(0.0009)$ \\
\hline
\end{tabular}

Table 1: Stationarity results of the variables - ADF test statistics results 1978-2015 
NPG Samantha, Liu Haiyun

The Impact of FDI on the Economic Growth of Sri Lanka: An ARDL Approach to Co-integration

\begin{tabular}{|l|l|l|ll|}
\hline$\Delta$ LogT & First difference & $-5.3663^{*}(0.0001)$ & $-5.3441^{*}(0.0006)$ \\
\hline$\Delta$ LogL & First difference & $-7.0416^{*}(0.0000)$ & $-7.0156^{*}$ & $(0.0000)$ \\
\hline
\end{tabular}

Notes: * significant at $1 \%$ and $* *$ significant at $5 \% . \Delta$ is used as a different operator. $\mathrm{P}$ values are in parenthesis.

Source: Author's computation,2017

Eviews 9.5 software is used to run ARDL approach to co-integration and the test result of equation 2 is shown in table 2 . The appropriate lag is selected automatically based on Schwarz Criterion and the selected ARDL model is $(1,0,1,0,0)$. The probability of F-statistics is less than 0.05 for the short-run model indicating its significance. Diagnostic tests such as serial correlation, normality test, and heteroscedasticity test were conducted to determine the validity of the data. The statistical value of heteroscedasticity is 1.49 and the probability level is 0.216 which is greater than 0.05. It is an indication of lack of heteroscedasticity of the model. As shown in Table 2, the short-run model gets through all the diagnostic tests. There is no serial correlation or autocorrelation and error term of the model is also normally distributed.

The estimated results of long-run coefficients are shown in Table 3. The long-run coefficient is an indicator of the long run relationship of the variables with the dependent variable. The sign of the coefficient of all the selected variables are positive in the long-run model, but only log DI (domestic investment) is significance at 1 percent level. Economic growth is positively correlated with FDI, trade openness and labor force in long run, but not significant. This is an indication of low productivity, less technological development and macroeconomic instability of the country. Wald test was run to compare the value of long-run coefficients with critical bounds. Table 4 shows the result of Wald test coefficient restrictions for the estimated model. The estimated Fstatistic of the Wald test is 8.822 and the upper critical bound is 4.73 , hence the null hypothesis of no co-integration is rejected. Meaning that a long-run relationship exists between the selected variables in the model. Through FDI is positively correlated with GDP, it is not significant for Sri Lankan in long-run.

The ECM of the selected ARDL model is shown in Table 5. The short-run elasticity of the variable is shown by the $\Delta$ sigh. According to the estimation results, only $\Delta \operatorname{logDI}$ is the significant factor for FDI - economic growth relationship in short-run for Sri Lanka. A negative sign of the error term is the indication of convergence towards the equilibrium. Hence the selected model converges to the equilibrium by adjusting 14 percent in in the first period. The estimated values of R2 and adjusted R2 are 0.59 and 0.58 respectively indicating that 59 percent of the variation of the dependent variable is explained by the independent variables. The Durbin-Watson test statistics of the error correction regression is 2.267 and it is an indication of lack of autocorrelation between the variables.

Table 2: ARDL estimation results

\begin{tabular}{|l|l|l|l|}
\hline \multirow{2}{*}{ Variables } & \multicolumn{3}{|c|}{ Dependent variable = logGDP } \\
\cline { 2 - 4 } Constant & Coefficients & t-statistics & Probability value \\
\hline logGDP(-1) & -0.630 & -1.001 & 0.321 \\
\hline logFDI & 0.861 & 11.131 & 0.000 \\
\hline $\operatorname{logDI}$ & 0.002 & 0.435 & 0.666 \\
\hline $\operatorname{logDI}(-1)$ & 0.174 & 5.129 & 0.000 \\
\hline $\log T$ & -0.091 & -2.429 & 0.021 \\
\hline $\log \mathrm{L}$ & 0.001 & 0.059 & 0.953 \\
\hline $\begin{array}{l}\mathrm{R}^{2}=0.99 \\
\text { Adjusted } \mathrm{R}^{2}=0.98 \\
\text { AIC }=-5.54\end{array}$ & 1.002 & 0.324 \\
\hline
\end{tabular}




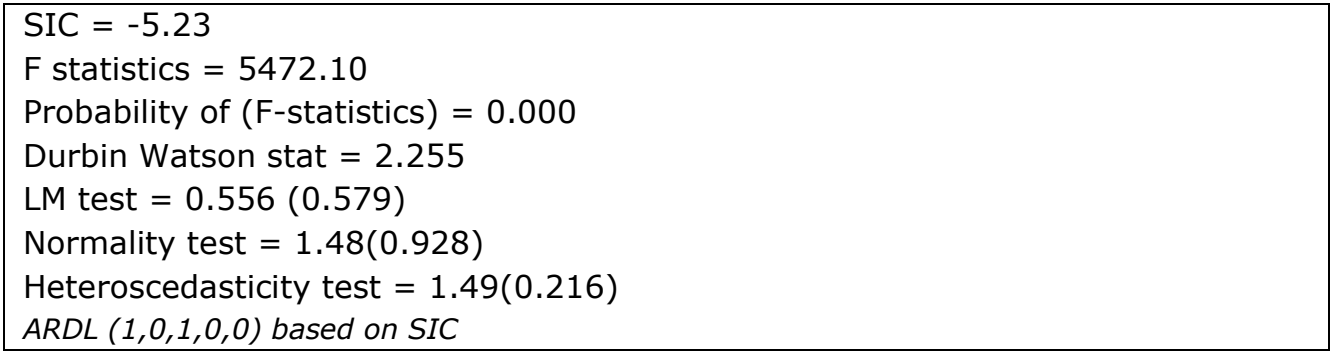

Source: Author's computation, 2017

Table 3: Estimation of long-run coefficients

\begin{tabular}{|l|l|l|l|}
\hline \multicolumn{4}{|c|}{ Dependent variable = log GDP } \\
\hline Variables & Coefficients & t-statistics & Probability value \\
\hline Constant & -4.5473 & -1.3485 & 0.1876 \\
\hline $\log F D I$ & 0.0203 & 0.4258 & 0.6733 \\
\hline $\log \mathrm{II}$ & 0.5779 & 3.5405 & 0.0013 \\
\hline $\log T$ & 0.0100 & 0.0585 & 0.9537 \\
\hline $\log \mathrm{L}$ & 0.7777 & 1.4398 & 0.1603 \\
\hline
\end{tabular}

Source: Author's computation, 2017

Figure 1 shows the CUSUM and CUSUMSQ stability tests respectively for the selected ARDL based ECM. This model is stable because none of the lines cross the critical value lines of figure plots generated by the Eviews software. Hence, this model can be applied to explain FDIeconomic growth relationship in Sri Lanka.

The empirical results related to FDI-growth relationship of Sri Lanka found a weak positive relationship in short run and long run. Akinlo (2004) finds a weak FDI-economic growth relationship in Nigeria where inward FDI mainly targeted oil extracting industries. Azman-Saini et al.(2010) also support this argument and emphasize that FDI on growth boost only after financial market development exceeds minimum required level. Haruna (2012) supports the argument that FDI does not much contribute to economic growth due to profit repatriations, interest payment on foreign loans and contract fees. Masry (2015) finds very weak and nonsignificant effect of FDI on economic.

Table 4: Wald test coefficient restriction

\begin{tabular}{|c|c|c|}
\hline Test statistics & Value & Probability \\
\hline F-statistics & 8.822 & 0.0001 \\
\hline$\chi^{2}$ & 35.29 & 0.0000 \\
\hline \multicolumn{3}{|c|}{ Critical value - Pesaran et al.(2001) } \\
\hline & Lower bound & Upper bound \\
\hline $1 \%$ & 3.29 & 4.37 \\
\hline $5 \%$ & 2.56 & 3.49 \\
\hline $10 \%$ & 2.20 & 3.09 \\
\hline
\end{tabular}

Source: Author's computation,2017 
NPG Samantha, Liu Haiyun

The Impact of FDI on the Economic Growth of Sri Lanka: An ARDL Approach to Co-integration

Table 5: Error correction representation for the selected ARDL model

\begin{tabular}{|c|c|c|c|}
\hline \multicolumn{4}{|c|}{ Dependent variable - $\Delta$ logGDP } \\
\hline Variables & Coefficients & t-statistics & Probability value \\
\hline$\Delta \log \mathrm{DI}$ & 0.1900 & 7.9839 & 0.000 \\
\hline $\operatorname{ECM}(-1)$ & -0.1401 & -12.053 & 0.000 \\
\hline \multicolumn{4}{|c|}{$\begin{array}{l}\mathrm{R}^{2}=0.593 \\
\text { Adjusted } \mathrm{R}^{2}=0.581 \\
\text { Durbin Watson }=2.267 \\
\mathrm{AIC}=-5.791 \\
\mathrm{SC}=-5.704 \\
\mathrm{HQC}=-5.760 \\
\text { ARDL }(1,0,1,0,0)\end{array}$} \\
\hline
\end{tabular}

Source: Author's computation, 2017

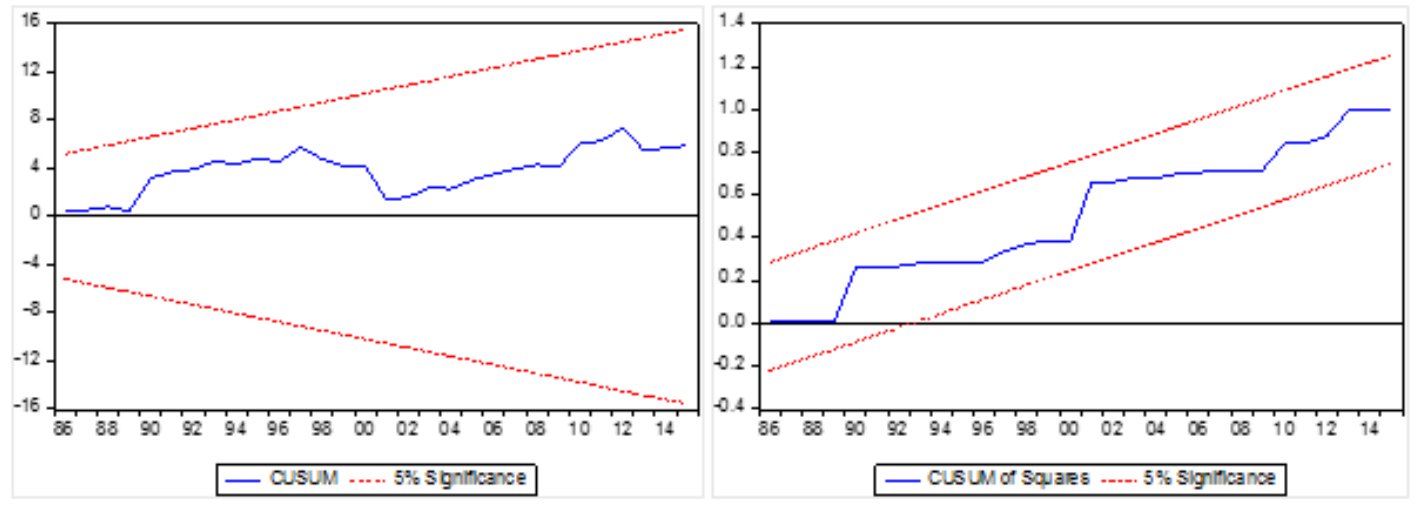

Figure 1: CUSUM and CUSUM square test for stability

Growth in Egypt due to failure in attracting labor-intensive FDI which create job opportunities. Adams (2009)finds a weak positive FDI-economic growth relationship in Sub-Sahara African countries. Belloumi (2014) finds insignificant causality between FDI and economic growth in Tunisia. Hence, the findings of the study are associated with previous research which found a weak FDI-economic growth relationship. The influence level of FDI on economic growth depends on the type and volume of inward FDI. According to the table 6, infrastructure development and services are the main targets of inward FDI of Sri Lanka. Sri Lanka needs to attract more Greenfield investments expanding manufacturing sector to increase export and economic growth. The weak FDI-economic growth relationship is a sign of lack of spillover effect form foreign firms to domestic firms. The link between local and foreign firms may be weak and in Sri Lanka, hence, this argument is indeed valid a country like Sri Lanka where domestic firms are having outdated technology. Sri Lanka is in the second stage of investment development path which FDI is attracted with the growth of income level and improvements in locationspecific advantage. Sri Lanka promoted to the middle-income category in 2010 and the geographic location is comparatively more attracted in inward FDI. The country needs to make use of this opportunities to attract more FDI in order to stimulate economic growth. 
NPG Samantha, Liu Haiyun

The Impact of FDI on the Economic Growth of Sri Lanka: An ARDL Approach to Co-integration

Table 6: FDI distribution by sectors (percentage of total)

\begin{tabular}{|l|r|r|r|r|r|}
\hline \multirow{2}{*}{ Sector } & \multicolumn{5}{|c|}{ Years } \\
\cline { 2 - 6 } Manufacturing & 2012 & 2013 & 2014 & 2015 & 2016 \\
\hline - Textile, Wearing Apparel \& Leather & $\mathbf{2 2 . 9 9}$ & $\mathbf{2 5 . 8 6}$ & $\mathbf{2 0 . 6 6}$ & $\mathbf{2 6 . 5 0}$ & $\mathbf{3 0 . 9 3}$ \\
\hline $\begin{array}{l}\text { - Chemicals, Petroleum, Coal, Rubber\& } \\
\quad \text { Plastics }\end{array}$ & 6.48 & 3.57 & 5.14 & 4.68 & 6.17 \\
\hline Agriculture & 4.42 & 8.22 & 5.69 & 7.78 & 12.43 \\
\hline Infrastructure \& Services & $\mathbf{0 . 5 4}$ & $\mathbf{0 . 6 1}$ & $\mathbf{0 . 3 5}$ & $\mathbf{0 . 4 0}$ & $\mathbf{0 . 2 4}$ \\
\hline Infrastructure & $\mathbf{7 6 . 4 8}$ & $\mathbf{7 3 . 5 3}$ & $\mathbf{7 3 . 5 5}$ & $\mathbf{7 3 . 1 0}$ & $\mathbf{6 8 . 8 4}$ \\
\hline - Housing \& Property Development & 44.58 & 56.55 & 42.22 & 46.76 & 42.38 \\
\hline - Telephone \& Telecommunication & 4.17 & 15.64 & 20.99 & 21.87 & 9.92 \\
\hline$\quad$ Network & & & & & \\
\hline Services & 18.09 & 25.86 & 9.43 & 14.32 & 30.41 \\
\hline - Hotels \& Restaurants & 31.89 & 16.99 & 31.33 & 26.34 & 26.45 \\
\hline Total FDI(US\$ Million) & 8.77 & 4.88 & 4.23 & 18.76 & 17.64 \\
\hline
\end{tabular}

Source: BOI Sri Lanka

\section{Conclusion and Recommendations}

The aim of this study is to find out FDI-economic growth relationship of Sri Lanka for the period of 1978-2015. The selected variables are real FDI inflows, domestic investment, trade openness and labor force to identify the impact on economic growth. Sri Lanka is seeking FDI to boost economic growth at present, hence, it is motivated identifying whether FDI promotes economic growth on prevailing economic setting. We used ADF unit root test to find out the order of integration of the variable. Due to Variables are stationary at different levels I (0) and I (1) we applied ARDL approach to co-integration along with ECM to find out the long run relationship and short-run dynamics between the selected variables. F-statistics Wald coefficient restriction test confirmed the long-run relationship between the variables. The ECM generated expected sigh at 1 percent significant level. The selected econometric model gets through all the diagnostic tests and confirms the absence of serial correlation, heteroscedasticity, and nonnormality. CUSUM and CUSUMSQ tests confirm the stability of the model validating the applicability in policy making for Sri Lanka.

The empirical results the study are associated with previous research which found a weak relationship between FDI and economic growth. Among the other selected variables, domestic investment is found as the main driver of economic growth in Sri Lanka. FDI is weakly and positively correlated with economic growth in the long run. Sri Lanka will have to undertake policy reforms related to FDI in order to attract more greenfield investment to boost economic growth creating new job opportunities and expanding exports in the manufacturing sector. These findings would be an example for other small open economies with similar economic characteristics.

\section{Acknowledgements}

Authors would like to express their gratitude to reviewers and editors of the journal for their comments and suggestions on the previous version of this paper. 


\section{References}

- Adams, S. (2009). "Foreign Direct investment, domestic investment, and economic growth in Sub-Saharan Africa", Journal of Policy Modeling, 31(6), 939-949. Crossref

- ADB. (2016). Asian development outlook 2016:"Asia's potential growth", Asian Development Bank. http://www.adb.org/publications/asian-development-outlook-2016-asia-potentialgrowth

- Agrawal, G. (2015). "Foreign Direct Investment and Economic Growth in BRICS Economies: A Panel Data Analysis", Journal of Economics, Business and Management, 3(4), 421-424. Crossref

- Agrawal, G., \& Khan, M. a. (2011). "Impact of FDI on GDP: A Comparative Study of China and India", International Journal of Business and Management, 6(10), 71-79. Crossref

- Akinlo, A. E. (2004). "Foreign direct investment and growth in Nigeria. An empirical investigation", Journal of Policy Modeling, 26(5), 627-639. Crossref

- Alfaro, L., Chanda, A., Kalemli-Ozcan, S., \& Sayek, S. (2010). "Does foreign direct investment promote growth? Exploring the role of financial markets on linkages", Journal of Development Economics, 91(2), 242-256. Crossref

- Athukorala, P. (2003). "The impact of foreign direct investment for economic growth: A case study in Sri Lanka", 9th International Conference on Sri Lanka Studies, (92), 1-21. http://www.freewebs.com/slageconr/9thicslsflpprs/fullp092.pdf

- Azman-Saini, W. N. W., Law, S. H., \& Ahmad, A. H. (2010). "FDI and economic growth: New evidence on the role of financial markets", Economics Letters, 107(2), 211-213. Crossref

- Balasubramanyam, V. N., M. Salisu, \& David, S. (1996). "Foreign Direct Investment and Growth in EP and IS Countries", The Economic Journal, Vol. 106(434 (Jan. 1996)), 92-105. Crossref

- Belloumi, M. (2014). "The relationship between trade, FDI and economic growth in Tunisia: An application of the autoregressive distributed lag model", Economic Systems, 38(2), 269287. Crossref

- Bengoa, M., \& Sanchez-Robles, B. (2003). "Foreign direct investment, economic freedom, and growth: New evidence from Latin America". European Journal of Political Economy, 19(3), 529-545. Crossref

- Borensztein, E., De Gregorio, J., \& Lee, J.-W. (1998). "How does foreign direct investment affect economic growth?", Journal of International Economics, 45(1), 115-135. Crossref

- Chaudhry, N. I., Mehmood, A., \& Mehmood, M. S. (2013). "Empirical relationship between foreign direct investment and economic growth: An ARDL co-integration approach for China", China Finance Review International, 3(1), 26-41. Crossref

- Engle, R. F., \& Granger, C. W. J. (1987). "Co-integration and error correction: representation, estimation and testing", Econometrica, 55, 251-276.

- Falki, N. (2009). "Impact of Foreign Direct Investment on Economic Growth in Pakistan". International Review of Business Research, 5(5), 110-120. Crossref

- Fedderke, J. W., \& Romm, A. T. (2006). "Growth impact and determinants of foreign direct investment into South Africa, 1956-2003", Economic Modelling, 23(5), 738-760. Crossref

- Gao, T. (2005). "Foreign direct investment and growth under economic integration", Journal of International Economics, 67(1), 157-174. Crossref

- Granger, C. W. J., \& Newbold, P. (1974). Spurious regression in econometrics. Journal of Econometrics, 2, 111-120.

- Hakimi, A., \& Hamdi, H. (2016). "Trade liberalization, FDI inflows, environmental quality and economic growth: A comparative analysis between Tunisia and Morocco", Renewable and Sustainable Energy Reviews, 58, 1445-1456. Crossref

- Hansen, H., \& Rand, J. (2006). "On the causal links between FDI and growth in developing countries", World Economy, 29(1), 21-41. Crossref

- Haruna Danja, K. (2012). "Foreign Direct Investment and the Nigerian Economy", American Journal of Economics, 2(3), 33-40. Crossref 
- Herzer, D., Klasen, S., \& Nowak-Lehmann D., F. (2008). "In search of FDI-led growth in developing countries: The way forward". Economic Modelling, 25(5), 793-810. Crossref

- Iamsiraroj, S., \& Ulubaşoğlu, M. A. (2015). "Foreign direct investment and economic growth: A real relationship or wishful thinking?", Economic Modelling, 51, 200-213. Crossref

- Johansen, S., \& Juselius, K. (1990). "Maximum likelihood estimation and inference on cointegration with application for the demand for money", Oxford Bulletin of Economics and Statistics, 52, 169-210.

- Mahmood, M. T. (2013). "Does Foreign Direct Investment Influence Economic Growth and Human Capital of Host Countries? A Review of Empirical Evidence", World Applied Sciences Journal, 21(8), 1116-1121. Crossref

- Makki, S. S., \& Somwaru, A. (2004). "Impact of Foreign Direct Investment and Trade on Economic Growth", American Journal of Agricultural Economics, 86(3), 795-801.

- Maliwa, E., \& Nyambe, J. M. (2015). "Investigating the impact of FDI on economic growth in Zambia: 1980 - 2012", European Journal of Business, Economics and Accountancy, 3(3), 41-50.

- Masry, M. (2015). "Does Foreign Direct Investment (FDI) Really Matter in Developing Countries? The Case of Egypt", Research in World Economy, 6(4), 64-77. Crossref

- Pesaran, M. H., Shin, Y., \& Smith, R. J. (2001). "Bounds testing approaches to the analysis of level relationships", Journal of Applied Econometrics, 16(3), 289-326. Crossref

- Romer, P. M. (1986). "Increasing Returns and Long-Run Growth", The Journal of Political Economy, 94(5), 1002-1037. http://www.jstor.org/stable/1833190

- Saqib, N., Masnoon, M., \& Rafique, N. (2013). "Impact of Foreign Direct Investment on Economic Growth of Pakistan", Advances in Management \& Applied Economics, 3(1), 35-45. Crossref

- Silajdzic, S., \& Mehic, E. (2016). "Absorptive Capabilities, FDI, and Economic Growth in Transition Economies", Emerging Markets Finance and Trade, 52(4), 904-922. Crossref

- Solow, R. M. (1957). "Technical Change and the Aggregate Production Function", The Review of Economics and Statistics, 39(3), 312-320.

- Soltani, H., \& Ochi, A. (2012). "Foreign Direct Investment (FDI) and Economic Growth: an approach in terms of cointegration for the case of Tunisia", Journal of Applied Finance \& Banking, 2(4), 193-207. http://www.scienpress.com/Upload/JAFB/Vol 2_4_13.pdf

- Tsai, P.-L. (1995). "Foreign Direct Investment and Income Inequality: Further Evidence". World Development, 23(3), 469-483. Crossref

- Zilinske, A. (2010). "Negative and Positive Effects of Foreign Direct Investment". Economics and Management, 15, 332-336. 